Volume 11, Issue 12, December 2020, pp. 269-277. Article ID: IJM $11 \_12026$

Available online at http://iaeme.com/Home/issue/IJM?Volume $=11 \&$ Issue $=12$

Journal Impact Factor (2020): 10.1471 (Calculated by GISI) www.jifactor.com

ISSN Print: 0976-6502 and ISSN Online: 0976-6510

DOI: 10.34218/IJM.11.12.2020.026

\title{
KEY ELEMENTS OF SOCIAL ENTERPRISE MANAGEMENT: CASE STUDY OF IRRIGATION WATER MANAGEMENT, KHAMMOUANE DISTRICT, LAO PDR
}

\author{
Kham Hou Phanthavong and Phithagorn Thanitbenjasith \\ Business Administration Department, Faculty of Business Administration, \\ North - Chiang Mai University, Thailand
}

\begin{abstract}
This research aimed to study key elements of social enterprise management in irrigation water management in Khammouane Province through the use of constructivism and participatory action research. Moreover, strategies of inquiry and case study were also applied. Its 12 key Informants were selected by the author using purposive sampling method and divided into 3 following groups: 1) government officials and academicians involving the irrigation water management; 2) private business sector in agriculture; and 3) other related person and group of farmers in Khammouane Province. The data were collected through in-depth interviews along with data analysis by means of content and document analysis. The study results showed that the adoption of enterprise management concept according to business principles focusing on sustainable wealth creation for society should have contributory characteristics and elements for efficient irrigation water management, namely, participation in ownership, mutual help in community management, fair sharing, government support, innovation and competitiveness, enhancement of community's role and strength; clear formulation of common policies, organizational vision, management under business principles focusing on promotion of social stability, collaborative learning, training, constant monitoring for evaluation, enforcement of rules and regulations to control water resource use and profit sharing in doing business to generate income for members. Besides, the relevant agencies needed to focus on and formulate policies for promotion and development of social enterprise in Lao PDR the achievement of both business operations and social impacts. This would pave the way to the sustainable development of economy, society and environment in Lao PDR.
\end{abstract}


Key Elements of Social Enterprise Management: Case Study of Irrigation Water Management, Khammouane District, Lao PDR

Key words: Irrigation water, Management, Social Enterprise, Lao PDR.

Cite this Article: Kham Hou Phanthavong and Phithagorn Thanitbenjasith, Key Elements of Social Enterprise Management: Case Study of Irrigation Water Management, Khammouane District, Lao PDR, International Journal of Management, 11(12), 2020, pp 269-277.

http://iaeme.com/Home/issue/IJM?Volume $=11 \&$ Issue $=12$

\section{INTRODUCTION}

\subsection{Background and Significance of Problems}

The private organizations' actions to increase social responsibility are likely to soar steadily revealing the intention of entrepreneurs and organizations to give their hands in community and society development along with business operations. By doing so, it may begin with activities known as 'Corporate Social Responsibility (CSR)' before turning into 'Corporate Social Engagement', both of which are social activities done by the organization or business in parallel with profit making. However, at present, the social development known as "Social Enterprise" (SE) is regarded as the other development of activities in which the operations of organization or business concern or bind with products and/or services that mainly helps solving problems or developing society, community, environment without the goal of making maximum profit. The operations still follow business growth principle; generate income; and contribute to sustainable development by taking into account the stance of social responsibility or social development. Therefore, the achievement of 'social enterprise' is both success of business operations and social impact (Jatupon Jui Jai-ngam, 2013; Sakda Siripatsopon, 2015).

The social enterprise concept has been emerged and developed in many countries worldwide, especially in the United States and Western Europe since the mid- $19^{\text {th }}$ century (Defourny \& Kim, 2011). It is a tool reducing social problems in communities by closing gaps among people; creating more fairness and reasonably and sustainably lessening environmental problems derived from capitalism (Jatupon Jui Jai-ngam, 2013). The social enterprise is a business that aims at solving problem and developing community, environment and society. It is not merely an operation with a primary goal to make the highest profit for owners or stakeholders. Rather, it is planned and operated for survival through efficient business mechanisms and stable business development based on strong financial position allowing the generation of profits for problem solving and for social and environmental development. This was to achieve the balance in 3 areas under "Triple Bottom Line" principle (Elkington, 1997) in order to create social benefits e.g. strengthening of local communities, community infrastructure development, job creation, generation of income for better standard of living. Also, there must be the environmental return e.g. environmental conservation, maintenance and restoration, while natural resource use that causes environmental and global impacts should be reduced to the lowest level. Meanwhile, all these should be based on economic return or profit for the enterprise's survival and contribution for sustainable change (Kewolin Mali, 2014).

The Democratic Republic of Lao People (Lao PDR), one of the ASEAN members, is steering its development in line with economic growth and changing global context. This is evidenced by economic growth rate and average annual gross domestic productivity (GDP) in $2015-2018$ at $2.9 \%$ as a result of manufacturing and industrial sectors. Also, the agricultural sector is one of the driving factors of economic growth. As the world is seeking for the sustainability from the country's primary industry, the agriculture thus becomes the most important economic sector. More than $80 \%$ of Lao PDR's workforce is in agricultural sector 
and the agricultural area is approximately $20 \%$ of its total area. Most arable area is in the lowland across central and southern regions, while the northern Laos is characterized by mountainous and plateau terrain making it unsuitable for cultivation (Ministry of Agriculture and Forestry, Lao PDR, 2016). According to Agricultural and Forestry Development Strategy 2016-2025 and Vision 2030 of the Ministry of Agriculture and Forestry under Lao PDR's $8^{\text {th }} 5$ Year National Economic and Social Development Plan (2016-2020), the growth of agriculture and forestry at least $4-5 \%$ per year is determined. The agriculture is the manufacturing sector that is sensitive to weather and changing climate. Therefore, the development of agricultural sector into important economic sector relies on water as a principal manufacturing factor. However, the unbalance between water and demand has impacts on agricultural sector. For example, the drought owing to inadequate water causes dehydration and death of crops and shortage of food and water for livestock. Meanwhile, excessive water will result in flood and damaged crops. Farmers eventually have no income and are indebted. The investment in agriculture sector thus requires balanced and suitable water management, which is a key for production in agricultural sector. This is due to the fact that the imbalanced water management will affect the agricultural sector and country's overall development.

In spite of government's policy in supporting group formation, problems in the irrigation water management among groups of irrigation water users are found resulting in inefficient water management in that area. Due to the lack of irrigation plan for agricultural areas, some areas may receive excessive or insufficient water in one given production season leading to failure of productivity to meet target and loss of farmers (Ministry of Agriculture and Forestry, Lao PDR, 2016). Besides, the irrigation water management in the form of a committee in Lao PDR has no responsibility of irrigation canal maintenance. Some canals are shallow and lack reparation, while some of them are completely built but not utilized. As a result, the formation of water user group is inconsistent with the government's goal, which is expected to welcome water users, as the direct stakeholders in water use, to play a role in such management. On the contrary, irrigation water users are found to be not familiar with work in team and to lack both participation in ownership and fund for irrigation system maintenance (Ministry of Agriculture and Forestry, Lao PDR, 2016).

The irrigation water management in Lao PDR is a key to its economic development because agricultural produce is main income. Hence, efficient irrigation water management affects agricultural sector. Its current irrigation water management managed by public sector is not very efficient (Ministry of Agriculture and Forestry, Lao PDR, 2016). Changes of business management model and mutual benefit of stakeholders in water use is a solution to social problems on the basis of business model. It focuses on sharing of returns to group members, while stakeholders can play a role with the government's support in solving problems in the society or in the community itself.

Due to this problem, the author is interested in studying the application of social enterprise management model in irrigation water management so that people in community gain more benefit from suitable management (Social Enterprise UK, 2016). This is regarded as a huge challenge in the management because it is important to consider both benefit in terms of income and overall impact on community (Battilana \& Lee, 2014; Doherty et al., 2014; Ebrahim et al., 2014; Stevens et al., 2015). This is to eventually introduce sustainable solutions to irrigation water management problems in Lao PDR.

\section{RESEARCH METHODOLOGY}

This research aims to study key elements of social enterprise management in irrigation water management at Khammouane District, Lao PDR. It uses constructivism and participatory action research as an alternative for knowledge claim (Creswell, 2009) and for answering 
Key Elements of Social Enterprise Management: Case Study of Irrigation Water Management, Khammouane District, Lao PDR

questions of beliefs about natural agreement of truth, relationship between truth and truth seeker as well as mean for truth seeking. This is the qualitative research (Cresswell, 2003; Patton, 2002) in which interviews and document studies are the main tool for data collection. The author also uses strategies of inquiry and study because this research needs in-depth answers through detailed studies and profound data collection from multiple and thorough sources within the context of this study, which is specific and in line with qualitative approach (Creswell \& Clark, 2007).

In this study, there are 12 key informants, divided into three groups: 1) government officials and academics involved in irrigation water management, 2) private business sector in agricultural areas, and 3) other stakeholders and farmer groups in Khammouane District. The author chooses them using purposive sampling method in line with informant determination for qualitative research (Guest, Bunce, \& Johnson, 2006; Kuzel, 1999, cited in B.Marshall et al., 2013) to obtain information that most closely matches research objectives (Creswell, 2007). The interview form, verified by senior experts in light of content validity and language use is research tool and in-depth interview is conducted. The author carries out content and documentary analysis of domestic and international books, articles and related research papers in order to examine and collect additional data related to social enterprises so that research results are most contextually suitable. For analysis of data obtained from interviews, the author has categorized and summarized them (Miles \& Huberman, 1984) to ensure data accuracy in terms of rigor criteria. Moreover, the author also applies triangulation technique to the findings and interpretation of collected data for greater trustworthiness (Lincoln \& Guba, 1985).

\section{RESULTS AND DISCUSSION}

The study results give answers to research questions that "what are elements/ factors of social enterprise management in irrigation water management and what they consist of". This is based on results of interviews with key informants and on related issues, which are regarded as the answers to research questions. The details of data analysis are as follows.

\subsection{Meaning of Social Enterprise Concept}

The social enterprise concept means mutual assistance of people in a community or area, maximized use of locally available resources, job creation in community to generate income, strengthening of security, solving community's problems/conflicts, pursuit of business based on common interests, human resource development to augment operation ability and knowledge and social enterprise establishment in community focusing on self-reliance. (Pearce \& Kay, 2003; Harding \& Cowling, 2006; Zahra, Gedajlovic, Neubaum, \& Shulman, 2009; Martin \& Novicevic, 2010; Office of the Promotion of National Social Enterprise, 2010)

\subsection{Factors Affecting Social Enterprise Management}

The external factors affecting business management focusing on sustainable wealth creation for society include law and politics, policies and public budgets, economy, environment, climate change, society and culture as well as technology.

The internal factors affecting business management focusing on sustainable wealth creation for society are human resource and labor, administrative and management system, finance and budget as well as products, goods or services. 


\subsection{Business Management Elements focusing on Sustainable Wealth Creation for Society}

Business management elements focusing on sustainable wealth creation for society include planning, targeting, verification and monitoring, financial, budget/cost management, human resources, labor, business ownership and business involvement, technology, research and development, marketing, leader and leadership, organization's regulations, strategic plans structures and visions, social mission and business strategy, practice and operation, equipment/ facilities/tools/machinery and participation in business operation. The study results agree with the Stock Exchange of Thailand (2014) and the Office of the Promotion of National Social Enterprise (2010) in terms of social mission, social ownership, stakeholder engagement, operation of social enterprise and scalability apart from profit making and business maintenance.

\subsection{Current Water Management in Lao PDR \\ Irrigation Water Management Process of Lao PDR}

The irrigation water management process (Robbins \& Mary, 2018) includes a Plan (Planning): the management enabling farmers to use water during production season in farmlands, acquisition of information for planning, water management planning based on weirs and pumps and water user groups. The practical community planning is made with a clear division of work without causing waste. The plantation and production areas are designated in collaboration between the Royal Irrigation Department and water users. The management is planned under resources available, especially irrigation system structure. Do (Implementation): plans are implemented for the highest benefit, while water users are grouped according to individual projects. Different crops are properly specified by taking into account the economical use and adequate production along with centralized operations, nationwide water management and activities of the Royal Irrigation Department and water users. Check (Inspection): it means periodic monitoring, revision and improvement of plans, water use evaluation in an area, district-level monitoring, water use and opening and closing of water gates. Lastly, Act (Appropriate Action): the practice for the most appropriate course of action is determined. The participation from central to local levels plays an important role in problem solving and rehabilitation together with business stakeholders' important role in implementation and problem solving. The use of available resources in water management is maximized in collaboration with the Management Committee in that area. The compliance with laws, regulations and requirements follows the established guidelines.

\section{Problems and Obstacles in Management Process}

Problems and obstacles in management process found during the interviews are: insufficient budget for repairs or construction (some of them being canal ditches), lack of public sector's close and constant monitoring, incomplete design and construction of weirs, communities or beneficiaries' failure to protect their water use, insufficient number of public employees needed for responsibility sharing and for management and inadequate facilities in some areas. The water user group/water users' association committee still lacks inspection-related ability and knowledge, while the compliance is not as expected. The water users' lack of cooperation in marketing management is found and there is no guarantee for farmers in terms of product prices. This agrees with the study of Social Enterprise Nice Corp (2014) revealing that obstacles posed by social enterprise development concern lack of following matters, namely, stakeholders' understanding of social enterprises, clear or specific rules and regulations in such regard and business operation support. 
Key Elements of Social Enterprise Management: Case Study of Irrigation Water Management, Khammouane District, Lao PDR

\subsection{Current Water Management in Khammouane District}

\section{The Current Pursuit of Water Management in Khammouane District}

Input: insufficient budget and public officials, inadequate labor, equipment, tools and machinery and outdated materials, equipment, tools and machinery, Process: water users' insufficient water management knowledge to follow the established plans resulting in conflicts of excessive and less water use, inefficient mechanism for coordination among farmers or between farmers and government, and demand for constant improvement, Output: insufficient or poor quality water, inferior agricultural produces, conflicts among water users, adequate water supply for agricultural activities and for electricity generation

\section{Problems or Obstacles of Current Water Management in Khammouane District in Each Aspect}

Problems or obstacles of current water management in Khammouane District in each following aspect are found: insufficient budget, financial and accounting system, being indebted and unduly payments, water user associations' poor management, problems in production planning, insufficient and outdated machinery and tools, insufficient or poor manufacturing, marketing problems, unsuitable production planning within local context, deteriorated buildings or structures of irrigation systems for water management, community leaders' deficiency of knowledge and ability and lack of government support. All these are consistent with the studies of Kewolin Mali (2014) and Social Enterprise Nice Corp (2014) concerning the ability of capital management and lack of support for business operations.

\subsection{Improvement of the Efficiency of Irrigation Water Management}

The improvement of efficiency of irrigation water management requires the following management. For example, the government has to monitor and evaluate the formation of groups that work with communities and to give advices on relevant academic techniques. In, addition, the government must also regularly take part in suggesting how to use water for the benefit of areas; providing knowledge and trainings; closely and constantly enhancing water users; as well as developing and strengthening water users in terms of their role and awareness of importance of water. The production process should be changed with the use of machinery and technologies for saving of cost, time and labor and for greater quantity and amount of products. The manufacturing and water user groups are founded in compliance with mechanisms, rules and regulations on water user protection. The marketing planning and survey aim to generate income for communities and to produce goods in line with the demand of market along with budget support in the operations for better management. The adoption of modern technologies in opening and closing water gates ensure the effective discharge of water into farmlands in accordance with the output. The work plans are clearly designated on the basis of construction and design that are truly consistent with society and water users enabling them to best use water for communities in manufacturing, water supply and tourism. The policy formulation considers the production input e.g. fertilizer, machinery and pump to foster production according to the established mechanical system. The participation in management benefits common interests of different organizations such as water users' associations. This action conforms to the study of the Stock Exchange of Thailand (2014) on development of infrastructure systems/networks/intermediary organizations in efficiently supporting operations. The strengthened group formation contributes to strong organizational management and to clear designation of duties and responsibilities resulting in the efficient steering of social enterprise. 


\subsection{Efficient Irrigation Water Management}

The important elements of efficient irrigation water management include strong group formation, planning, monitoring and evaluation in collaboration with communities in exploring problems, improvements and solutions. Good budget management is done through the arrangement of working capital within the group. The government formulates the policy and introduces suitable plans for water use and production. The organization is established with direct responsibilities for water management and for management and restoration of irrigation system structure according to actual conditions in that area. This is to create local people's awareness of water use along with introduction of managerial rules and regulations to support effective work. The meetings and trainings are arranged in order to mutually exchange knowledge. Private organizations engage in marketing promotion and fundraising, while farmers and manufacturers in the area help maintaining efficient irrigation structure and system. The management process is developed in accordance with community context so that the community can best use the available resources including receipt of government's support in terms of management/materials/equipment/tools/machinery/transportation. The production is planned to suit the crops to be grown, while trainings on the use of technologies are provided for personnel.

\subsection{Contributory Characteristics and Key Elements for Efficient Irrigation Water Management under Business Principles Focusing on Sustainable Wealth Creation for Society}

The adoption of enterprise management concept according to business principles focusing on sustainable wealth creation for society should include contributory characteristics and elements for efficient irrigation water management, namely, participation in ownership, mutual help in community management, fair sharing, government support, innovation and competitiveness, enhancement of community's role and strength; clear formulation of common policies, organizational vision, management under business principles focusing on promotion of social stability, collaborative learning, training, constant monitoring for evaluation, enforcement of rules and regulations to control water resource use and profit sharing in doing business to generate income for members. The elements obtained from this study are consistent with the study of the Stock Exchange of Thailand, (2014) in light of support through government policy, development of infrastructure/network/intermediary organizations in providing support and developing human capital.

\section{SUMMARY AND RECOMMENDATION}

The social enterprise development is a new issue in Lao PDR requiring concrete development. The social enterprise is the operation of an agency or organization focusing on solutions to social and environmental problems, while benefits from business operations are still enjoyed so that the organization can survive in the future in a sustainable manner. It needs cooperation from different sectors in the operations with a focus on the creation of innovations to solve social and environmental problems that arise and change rapidly. With respect to the analysis of study results of social enterprise concept through interviews with key informants, the elements of social enterprise as summarized by the author are as follows: planning, targeting, monitoring and follow-up, financial, budget/cost management, human resource, labor, business ownership and involvement in business operations, research and development technology, leader and leadership, strategic plan and organizational vision, business goals and strategies, actions and operations, equipment/facilities/tools/machinery, participation in business operations and organization's structure and processes. Meanwhile, the adoption of enterprise management concept focusing on sustainable wealth creation for society consists of 
Key Elements of Social Enterprise Management: Case Study of Irrigation Water Management, Khammouane District, Lao PDR

following contributory characteristics and elements for efficient irrigation water management: participation in ownership, mutual help in community management, fair sharing, government support, innovation and competitiveness, enhancement of community's role and strength; clear formulation of common policies, organizational vision, management under business principles focusing on promotion of social stability, collaborative learning, training, constant monitoring for evaluation, enforcement of rules and regulations to control water resource use and profit sharing in doing business to generate income for members. In addition, the concerned government agencies and private sector need to realize the importance as well as formulate policies and appropriate measures for promoting and developing social enterprise in Lao PDR for the enjoyment of efficient, stable and sustainable growth.

\section{REFERENCES}

[1] Battilana, J., \& Lee, M. (2014). Advancing Research on the Hybrid Organizing: Insights from the Study of Social Enterprise. The Academy of Management Annals, 8(1), 397-441.

[2] Corbin, J., \& Strauss, A. (2008). Basics of Qualitative Research: Techniques and Procedures for Developing Grounded Theory (3rd ed.). Thousand Oaks, CA: SAGE.

[3] Cresswell, J.W. (2003). Research Design: Qualitative, Quantitative, and Mixed Methods Approaches ( $2^{\text {nd }}$ ed.). Thousand Oaks, CA: Sage.

[4] Cresswell, J.W. (2009). Research Design: Qualitative, Quantitative, and Mixed Methods Approaches $\left(3^{\text {rd }}\right.$ ed. $)$. Thousand Oaks, CA: Sage.

[5] Creswell, J. W., \& Plano Clark, V. L. (2007). Designing and Conducting Mixed Methods Research. Thousand Oaks, CA: Sage.

[6] Defourny, J. \& Kim, S. (2011). Emerging models of social enterprise in Eastern Asia: A crosscountry analysis. Social Enterprise Journal, 7(1): 86-111.

[7] Doherty, B., Haugh, H., \& Lyon, F. (2014). Social enterprises as hybrid organizations: A review and research agenda. International Journal of Management Reviews, 16: 417-436

[8] Ebrahim, A., Battilana, J., \& Mair, J. (2014). The governance of social enterprises: Mission drift and accountability challenges in hybrid organizations. Research in Organizational Behavior, 34: 81-100.

[9] Elkington, J. (1997). Cannibals with Forks: The Triple Bottom Line of Twenty-First Century Business. Capstone, Oxford.

[10] Eisner, E.W. (1985). The Educational Imagination: On the design and evaluation of school programs. New York: Macmillan Publishing.

[11] Eisner, E.W. (1998). The enlightened eye: Qualitative inquiry and the enhancement of educational practice. Ohio: Prentice Hall.

[12] Guba, E. G. (1990). The alternative paradigm dialogs. In Guba, E.G. (Ed.). The Paradigm Dialog. (pp.45-57). Newbury Park, CA: Sage.

[13] Harding, R., \& Cowling, M. (2006). Social entrepreneurship monitor. London: Global Entrepreneurship Monitor.

[14] Jatupon Jui Jai-ngam. (2013). Social enterprise, trends of modern capitalism, a successful case study. Silpakorn University, 7 (1), 112 - 126.

[15] Kewolin Mali. (2014). Social enterprise in Thailand. Journal of Economics and Management Strategy Kasetsart University Sriracha Campus, 1 (2), 104-112.

[16] Lincoln, Y.S., \& Guba, E.G. (1985). Naturalistic Inquiry. Beverly Hills, CA: Sage. 
[17] Marshall, B., Cardon, P., Poddar, A., \& Fontenot, R. (2013). Does sample size matter in qualitative research? A review of qualitative interviews in IS research. Journal of Computer Information Systems, 54, 11- 22. doi:10.1080/08874417.2013.11645667

[18] Martin, J. S., \& Novicevic, M. (2010). Social entrepreneurship among Kenyan farmers: A case example of acculturation challenges and program successes. International journal of intercultural relations, 34(5), 482-492.

[19] Miles, M.B. \& Huberman, A.M. (1984). Qualitative Data Analysis: A Sourcebook of New Methods, Sage Publications, USA.

[20] Ministry of Agriculture and Forestry Lao PDR. (2016). Strategy of Ministry of Agriculture and Forestry, Lao PDR. Retrieved on June 10, 2018 from http://www.aseanthai.net/ewt_news.php?nid=5939\&filename=aseanknowledge

[21] Office of the Promotion of National Social Enterprise (2010). General knowledge about social enterprise. Retrieved 9 April 2018, from http://www.tseo.or.th/

[22] Patton, M. Q. (2002). Qualitative Evaluation and Research Methods (3rd ed.). Newbury Park, CA: Sage.

[23] Pearce, J., \& Kay, A. (2003). Social enterprise in any town: Calouste Gulbenkian Foundation.

[24] Robbins, Stephen P. \& Mary, Coulter K. (2018). Management. NY: Pearson Education.

[25] Sakda Siripatsopon. (2015). A study of the conceptual framework for social enterprise development. In Thailand. Journal of the Association of Researchers, Year 20 No. 2 May August 2015.

[26] Social Enterprise UK. (2016). "What are social enterprises?". Available at: www.socialenterprise.org.uk/about (accessed 4 January 2016).

[27] Social Enterprise Nice Corp: Social Enterprise (Social Enterprise). (2014). In the training of young investors for society, Class 22 (24 April 2014), Stock Exchange of Thailand, Bangkok.

[28] Stevens, R., Moray, N., \& Bruneel, J. (2015). The social and economic mission of social enterprises: Dimensions, measurement, validation, and relation. Entrepreneurship Theory \& Practice, 39: 1051-1108.

[29] The Stock Exchange of Thailand. (2014). Social enterprise can do good growth. Document for the New Generation Social Investor Project, Class 22.

[30] Zahra, S. A., Gedajlovic, E., Neubaum, D. O., \& Shulman, J. M. (2009). A typology of social entrepreneurs: Motives, search processes and ethical challenges. Journal of business venturing, 24(5), 519-532. 